\title{
Stressor dan Coping Stress Guru yang Dimutasi dari Sekolah Reguler ke Sekolah Luar Biasa (SLB)
}

\author{
Gede Angga Wiragita dan David Hizkia Tobing \\ Program Studi Psikologi, Fakultas Kedokteran, Universitas Udayana \\ davidhizkia@unud.ac.id
}

\begin{abstract}
Abstrak
Menentukan profesi yang diinginkan individu cenderung memilih pekerjaan sesuai dengan minat dan bakat yang dimiliki agar tidak terjadi ketidak sesuaian dalam bekerja. Semua profesi memiliki tingkat stress masing-masing. Profesi guru dilaporkan memiliki tingkat stress yang cukup tinggi jika dibandingkan dengan profesi lainnya. Guru yang ditugaskan di sebuah sekolah harus memiliki kemampuan dasar untuk memberikan pengajaran yang baik kepada siswa. Guru pada sekolah luar biasa (SLB) sebelum bertugas di SLB harus memiliki kemampuan dasar pendidikan luar biasa (PLB). Stress yang muncul pada individu dipengaruhi oleh banyak hal, salah satunya adalah ketidak sesuaian antara kemampuan yang dimiliki oleh individu dengan pekerjaan yang harus dikerjakan. Dalam menghadapi pemicu stress (stressor) individu melakukan coping stress guna meredam stress yang ditimbulkan oleh setiap pemicu stress (stressor). Penelitian ini bertujuan untuk mengetahui stressor yang dihadapi oleh guru yang dimutasi dari sekolah reguler ke sekolah luar biasa (SLB) serta coping stress yang dilakukan guna meredam stress yang ditimbulkan oleh stressor tersebut. Penelitian ini merupakan sebuah penelitian kualitatif yang menggunakan pendekatan studi kasus dengan desain kasus tunggal. Penggalian data dalam penelitian ini menggunakan teknik wawancara dan observasi. Responden penelitian ini adalah seorang guru yang dimutasi dari sekolah reguler ke sekolah luar biasa (SLB). Hasil dari penelitian ini menunjukkan bahwa responden menghadapi permasalahan pada awal penugasan di SLB dan permasalahan ketika mengajar di SLB. Coping stress yang dilakukan responden untuk mengatasi permasalahanpermasalahan yang dihadapi selama menjadi guru adalah dengan mencoba mencari solusi terbaik dari setiap permasalahan yang dihadapi responden.
\end{abstract}

Kata kunci: stress, stressor, coping stress, guru SLB

\begin{abstract}
In determining the desired profession, individuals tend to choose the work in accordance with the interests and talents that are owned in order to avoid incompatibility in work. All professions have their own stress level. Teachers professions are reported to have sufficiently high levels of stress when compared to other professions. Teachers assigned to a school must have a basic ability to provide good teaching to students. Teachers at special schools prior to serving in special shool must have the basic skills of extraordinary education. The stress that appears on the individual is influenced by many things, one of which is the incompatibility between the ability possessed by the individual with the work to be done. In the face of stressors individuals do coping stress to reduce the stress caused by each trigger of stress. This study aims to determine the stressors faced by teacher who transferred from regular school to special school and coping stress done to reduce stress caused by the stressor. This research is a qualitative research using case study approach with single case design. Excavation of data in this study using interview and observation techniques. The respondent of this research is a teacher who transferred from regular school to special school. The results of this study indicate that respondents face problems at the beginning of assignment in special school and problems when teaching in special school. Coping stress done by respondent to overcome the problems faced during becoming teacher is by trying to find the best solution from every problem faced by respondent.
\end{abstract}

Keywords: stress, stressor, coping stress, special school teacher 


\section{LATAR BELAKANG}

Menentukan profesi yang diinginkan individu cenderung memilih pekerjaan sesuai dengan minat dan bakat yang dimiliki agar tidak terjadi ketidaksesuaian dalam bekerja. Beberapa individu ada yang memilih bekerja didepan meja, bekerja dilapangan, bekerja didepan mesin, bekerja dengan manusia (Rahmawati, 2013). Bekerja didepan meja antara lain bekerja sebagai pegawai, receptionist, administrasi dan sebagainya. Bekerja dilapangan antara lain sebagai observer, relawan, sales dan sebagainya. Bekerja didepan mesin antara lain bekerja sebagai pekerja pabrik, memperbaiki mesin dan sebagainya. Bekerja dengan manusia antara lain sebagai pengacara, konsultan, dokter, perawat, tenaga pengajar (guru/dosen) (Rahmawati, 2013).

Pekerjaan dilapangan atau didepan meja atau dimana saja memiliki konsekuensi masing-masing seperti halnya stressor atau kondisi yang menyebabkan individu stress didalam bekerja. Menurut Nagel (2003) dalam Rahmawati (2013) menyebutkan bahwa individu yang bekerja berinteraksi atau berhubungan dengan individu rentan akan munculnya stress. Hasil dari penelitian yang dilakukan Nagel dengan memberi pertanyaan kepada keseluruhan responden mengenai kesempatan untuk memilih pekerjaan, 33\% menyatakan bekerja sebagai guru merupakan pekerjaan yang dapat memberikan stress dan $30 \%$ menyatakan akan bertahan bekerja sebagai guru selama 5 tahun. Hal ini menunjukkan bahwa bekerja sebagai guru memiliki tingkat stress yang tinggi dan berat.

Pada semua tingkat pendidikan (SD, SMP, SMA) peran guru sangat penting karena guru mempunyai tanggung jawab dalam proses belajar peserta didik (Prameswari, 2005). Peran sebagai guru dinilai sangat penuh tantangan, di satu sisi guru berperan dalam memberikan pengertian, ramah, sabar dengan siswa dan disisi lainnya guru harus mendorong mencapai tujuan siswa, memberi tugas, menegur dan memberi hukuman Winkel (1996) dalam Prameswari (2005). Dibandingkan antara guru yang mengajar di sekolah reguler dan guru yang mengajar di sekolah luar biasa (SLB), tingkat stress lebih tinggi pada guru yang mengajar di sekolah luar biasa (SLB) karena guru SLB lebih dominan dalam memberikan pengajaran dan perhatian yang lebih daripada guru sekolah reguler (Prameswari, 2005). Hal ini dikarenakan selain dalam memberikan pengajaran, guru harus lebih sabar dalam memberikan perhatian karena fokus belajar siswa SLB lebih rendah dibandingkan dengan siswa sekolah reguler, khususnya siswa SLB bagian C atau sekolah luar biasa bagi siswa tunagrahita yang memiliki skor IQ dibawah rata-rata siswa pada umumnya (Prameswari, 2005).

Sekolah luar biasa (SLB) bagian C adalah sekolah luar biasa yang diperuntukkan bagi siswa tunagrahita. Tunagrahita adalah individu yang memiliki intelegensi dibawah rata-rata yang disertai kesulitan beradaptasi dengan perilaku yang dimunculkan pada masa perkembangan dibandingkan dengan siswa pada umumnya (Astuti, 2011). Di Indonesia terdapat banyak SLB C/C1 yang dikhususkan bagi anak tunagrahita. Khususnya di Bali, terdapat tiga SLB C/C1 yang tersebar di tiga kabupaten yang berbeda yakni Kabupaten Tabanan, Kabupaten Buleleng, dan di Kota Denpasar.

Salah satu SLB yang berada di Kabupaten Buleleng yang berada di dekat pusat kota Singaraja merupakan tempat responden DA bekerja. Akses jalan ke SLB cukup memadai karena berada dekat dengan pusat kota Singaraja, namun di pagi hari, akses menuju ke SLB ini cukup padat karena banyak pedagang yang berjualan di sekitar areal sekolah seperti pedagang nasi kuning, jajanan, dan pedagang makanan sejenisnya. Kondisi ini diperparah dengan lalulintas yang padat serta keberadaan tempat penampungan sampah milik DKP Kabupaten Buleleng yang berada dekat dengan pintu masuk sekolah dimana keadaan ini menambah kesan "kumuh" pada lingkungan sekitar sekolah. SLB C yang terletak di Kabupaten Buleleng ini sendiri memiliki asrama untuk menampung siswa yang berasal dari pedesaan atau jauh dari pusat kota Singaraja.

Menurut Taylor (2009) stressor adalah segala hal yang dapat memunculkan stress seperti lingkungan yang tidak kondusif, suara bising, hubungan yang tidak harmonis dengan pekerjaan, teman atau pasangan dan tugas serta kewajiban terlalu berat yang dapat menimbulkan stress. Berbagai hal yang menyebabkan stress atau hal-hal yang dapat memicu munculnya stress disebut sebagai stressor. Ketika individu dihadapkan dengan lingkungan baru, proses adaptasi dari tiaptiap individu tentunya akan berbeda (Wiragita, 2016). Apalagi ketika lingkungan baru tersebut memiliki banyak perbedaan dari lingkungan sebelumnya. Proses adaptasi dengan lingkungan baru dalam hal ini lingkungan kerja yang baru memiliki stressor-stressor tersendiri, apalagi lingkungan yang baru memiliki perbedaan yang jauh berbeda dari lingkungan sebelumnya.

Stress dapat didefinisikan sebagai emosi negatif yang dimunculkan ketika menghadapi suatu hal yang tidak sesuai dengan prediksi, perubahan lingkungan dan faktor psikologis maupun biologis Baum (1990) dalam Taylor (2009). Stress juga dapat diartikan sebagai menghadapi sesuatu yang tidak sesuai dengan apa yang dipikirkan kemudian ada tantangan yang dapat memunculkan stress (Taylor, 2009). Menurut Atwater (1983) stress adalah berbagai perilaku yang dimunculkan dalam menghadapi lingkungan luar yang asing bagi diri individu. Terdapat dua pola yang berbeda dari stress, yaitu distres dan eustres Bernard (1968) dalam Atwater (1983). Distres didefinisikan sebagai stres yang bersifat negatif seperti tuntutan dari lingkungan luar yang menyebabkan individu menguras banyak energi dan dapat menyebabkan gangguan fisiologis, sedangkan eustres didefinisikan sebagai stress yang bersifat positif atau menyenangkan bagi individu.

Dimensi dari stress menurut Taylor (2009) adalah negative events, uncontrollable events, ambiguous events, overload. Negative events adalah stress yang dimunculkan karena kejadian yang bersifat negatif seperti pekerjaan yang terlalu berat, tidak sesuai dan harapan yang tidak terpenuhi. Uncontrollable events adalah stress yang ditimbulkan akibat situasi yang tidak terkontrol seperti sesuatu hal yang tidak dapat diprediksi sebelumnya. Ambiguous events adalah stress 
yang muncul dari kejadian yang tidak dipahami atau berada dalam situasi yang asing. Overload adalah stres yang ditimbulkan dari banyaknya orang yang berada disekitar kita atau tugas yang terlalu banyak sehingga dapat menjadi stressor.

Pemaparan diatas menunjukkan bahwa stress dapat muncul ketika individu harus menjalani proses adaptasi ketika dipindahkan ke lingkungan kerja yang baru, seperti yang dialami oleh DA, responden dalam penelitian ini. DA merupakan seorang laki-laki yang berprofesi sebagai guru. DA merupakan guru Agama Hindu di sekolah reguler (sekolah umum). DA dimutasi dari sekolah reguler tempat dia mengajar ke sekolah luar biasa (SLB) ketika belum genap 1 tahun menjadi guru di sekolah tersebut. DA ketika awal penugasan sempat merasa bingung harus menerapkan pola pengajaran seperti apa nanti ketika mengajar di SLB karena DA merupakan guru dengan latar belakang pendidikan sebagai guru reguler (sekolah umum) yang tidak mendapatkan dasardasar pendidikan luar biasa (PLB) untuk mengajar anak dengan kebutuhan khusus dalam hal ini siswa tunagrahita di SLB C. DA yang semula mengajar di sekolah reguler merasa asing dengan lingkungan kerja barunya yang sangat berbeda dengan lingkungan kerja sebelumnya. Selain tugas baru yang akan dikerjakan berbeda dengan tugas sebelumnya, lingkungan sekitar sekolah juga menurut DA menimbulkan stressor baru yang harus dia hadapi ketika awal DA mengajar di SLB.

Menurut Taylor (2009), stress dapat diatasi dengan berbagai cara. Terdapat mekanisme dalam mengatasi stress yaitu coping stress. Definisi dari coping stress adalah pikiran yang mengarahkan perilaku individu untuk mengorganisir atau memanajemen perilaku dari situasi yang penuh tekanan atau stressor (Taylor, 2009). Coping stress dimunculkan apabila muncul stressor yang dapat menimbulkan stress.

Dari pemaparan diatas, dengan melihat keterbatasan dalam proses penerimaan serta penyampaian informasi yang dimiliki siswa tunagrahita dimana siswa tunagrahita memiliki intelegensi dibawah rata-rata yang disertai kesulitan beradaptasi dengan perilaku yang dimunculkan pada masa perkembangan dibandingkan dengan siswa pada umumnya, maka akan memunculkan stress pada guru yang mengajar sehingga dapat mengganggu proses belajar di kelas. Berdasarkan permasalahan yang dialami oleh DA, peneliti ingin mengetahui hal-hal yang dapat menjadi stressor bagi guru SLB dan coping stress yang dilakukan guru SLB ketika stressor muncul. Dalam penelitian ini, salah satu guru SLB yang pernah mendapatkan mutasi dari sekolah reguler ke SLB akan dijadikan responden penelitian, sehingga diharapkan peneliti dapat menganalisis lebih mendalam stressor dan coping stress yang muncul pada guru SLB yang pernah dimutasi dari sekolah reguler ke SLB.

\section{METODE PENELITIAN}

\section{Desain Penelitian}

Penelitian ini menggunakan metode penelitian kualitatif. Yin (2016) menyatakan bahwa penelitian kualitatif sebagian besar mengandung kata-kata dan narasi-narasi, sedangkan menurut David Williams (dalam Moleong, 2004) penelitian kualitatif adalah penelitian yang menggunakan latar alamiah, dengan maksud menafsirkan fenomena yang terjadi dan dilakukan dengan jalan melibatkan berbagai metode yang ada. Dalam penelitian kualitatif, metode yang umumnya digunakan adalah wawancara dan observasi. Penelitian ini menggunakan metode penelitian kualitatif agar mendapatkan kesempatan membangun hubungan dengan responden, sehingga dapat melihat dunia dari sudut pandang responden penelitian (Strauss \& Corbin, 2015), yang dalam hal ini adalah pengalaman responden mengenai permasalahan selama mengajar di SLB serta bagaimana coping stress yang dilakukan responden ketika stressor-stressor muncul saat mengajar di SLB. Penelitian ini menggunakan metode penelitian kualitatif dengan pendekatan studi kasus. Studi kasus adalah uraian dan penjelasan komprehensif mengenai berbagai aspek seorang individu, suatu kelompok, suatu organisasi, (komunitas), suatu program, atau suatu situasi sosial (Mulyana, 2008). Woodside (2010) menyatakan bahwa studi kasus memiliki tujuan untuk mencapai suatu pemahaman mendalam dari proses-proses dan variabel konsep, seperti persepsi diri yang dimiliki partisipan dari proses berpikir, tujuan, dan pengaruh kontekstual yang diidentifikasi sebagai objektivitas dari prinsip studi kasus. Penelitian ini menggunakan pendekatan studi kasus untuk mendapatkan pemahaman yang mendalam terhadap responden beserta interaksi, perasaan, dan perilaku responden yang muncul pada waktu tertentu yang merupakan prinsip objektif dari studi kasus (Woodside, 2010) Penelitian ini menggunakan desain kasus tunggal, yaitu individu dengan pengalaman/kasus tertentu yang berfokus pada stressor serta proses coping stress guru yang mengajar di sekolah luar biasa (SLB).

\section{Unit Analisis}

Unit analisis merupakan satuan penelitian. Peneliti membuat pernyataan dan penjelasan deskriptif mengenai unit tersebut (Babbie, 2013). Unit analisis melakukan pendekatan studi kasus pada umumnya adalah komunitas, organisasi, atau perorangan (Pawito, 2007). Penelitian ini memiliki unit analisis, yaitu individu dengan pengalaman/kasus tertentu yang berfokus pada proses coping stress guru yang mengajar di sekolah luar biasa (SLB).

\section{Responden}

Sugiyono (2014) menyatakan bahwa pada penelitian kualitatif, peneliti memasuki situasi sosial tertentu, melakukan observasi dan wawancara kepada individu-individu yang dipandang mengetahui situasi sosial tersebut. Moleong (2004) menuliskan bahwa penelitian kualitatif tidak membatasi jumlah subjek yang diperlukan pada penelitian, sehingga dapat dengan bebas menentukan jumlah subjek sesuai dengan keperluan data yang dibutuhkan. Selain itu, proses penggalian data dapat dihentikan ketika data yang didapat bersifat jenuh. 
Menetapkan secara spesifik jumlah informan atau responden tidak diperlukan pada awal penelitian, walaupun diharapkan untuk mengindikasikan angka-angka yang dilibatkan sebagai sampel awal (Daymon dan Holloway, 2002). Penelitian ihi melibatkan seorang responden. Karakteristik dari calon responden dalam penelitian ini adalah sebagai berikut: Pertama, pernah mendapatkan mutasi dari guru di sekolah reguler ke sekolah luar biasa (SLB). Kedua, mengalami kesulitan ketika beradaptasi dengan lingkungan kerja yang berbeda dari sebelumnya (dari sekolah reguler ke SLB) Ketiga, tidak pernah mendapatkan dasar Pendidikan Luar Biasa (PLB) ketika dipindahkan ke SLB. Pernah dimutasi dari sekolah reguler ke sekolah luar biasa (SLB) menjadi karakteristik responden karena hal tersebut mempengaruhi kehidupan responden karena harus beradaptasi dengan lingkungan kerja jauh berbeda dari lingkungan kerja sebelumnya. Penelitian ini menggunakan purposive sampling, yaitu menetapkan karakteristik dari suatu populasi yang ingin diteliti dan mencoba menemukan individu yang memiliki karakteristik yang sesuai dengan tujuan penelitian ini (Johnson \& Christensen, 2014).

\section{Teknik Penggalian Data}

Menurut Sugiyono (2014), penggalian data dilakukan dalam berbagai setting, sumber, dan cara. Bila dilihat dari settingnya, data dapat dikumpulkan setting alamiah (natural setting), pada laboratorium dengan metode eksperimen, di rumah dengan berbagai responden, pada suatu seminar, diskusi, dijalan, dan lain-lain. Penelitian ini akan menggunakan teknik wawancara dan observasi dalam proses penggalian data. Peneliti membuat catatan lapangan setiap selesai melakukan kunjungan ke lapangan agar tidak melewatkan fakta-fakta penting yang merupakan informasi yang disampaikan oleh responden maupun informan. Pengamat dapat mencatat apa saja yang dikehendakinya. Catatan mungkin berupa laporan langkah-langkah peristiwa, dapat dibuat dalam bentuk kategori, atau dapat pula berupa catatan tentang gambaran umum yang singkat (Moleong. 2004).

\section{Teknik Analisis Data}

Miles dan Huberman (2014) mengamati bahwa analisis data dalam penelitian kualitatif terdiri dari tiga aktivitas yang terjadi secara bersama-sama, yaitu reduksi data (data reduction), penyajian data (data display), dan menarik kesimpulan/verifikasi (conclusion drawing/verification).

$\underline{\text { Reduksi data }}$

Reduksi data berarti merangkum, memilih hal-hal yang pokok, memfokuskan pada hal- hal yang penting, mencari tema dan pola. Didalam pelaksanaan reduksi data terdapat theoretical coding yang terdiri dari pengkodean berbuka (open coding), pengkodean berporos (axial coding), dan pengkodean berpilih (selective coding). Pengkodean berbuka adalah proses menguraikan, memeriksa, membandingkan, pengonsepan, dan mengategorikan data yang kemudian dilanjutkan dengan pengkodean berporos, yaitu seperangkat prosedur penempatan data kembali dengan cara-cara baru setelah pengkodean berbuka, dengan membuat kaitan antar-kategori dengan memanfaatkan paradigma pengkodean yang mencakup kondisi, konteks, strategi aksi/interaksi, dan konsekuensi. Pengkodean berpilih adalah proses pemilihan kategori inti terhadap kategori lainnya secara sistematis, pengabsahan hubungannya, mengganti kategori yang perlu diperbaiki dan dikembangkan lebih lanjut (Strauss \& Corbin, 2003).

$$
\text { Penyajian data }
$$

Aktivitas kedua pada analisis data penelitian kualitatif adalah penyajian data yang dapat dilakukan dalam bentuk uraian singkat, bagan, hubungan antar kategori, flowchart, dan sejenisnya. Melakukan penyajian dapat memudahkan individu untuk memahami apa yang terjadi, merencakan kerja selanjutnya berdasarkan apa yang telah dipahami tersebut.

\section{Penarikan kesimpulan/verifikasi}

Langkah ketiga dalam analisis data kualitatif adalah penarikan kesimpulan/verifikasi (Miles dan Huberman, 2014). Sugiyono (2014) menuliskan bahwa kesimpulan dalam penelitian kualitatif merupakan temuan baru yang belum pernah ada sebelumnya, Temuan dapat berupa deskripsi atau gambaran suatu obyek yang sebelumnya masih kurang jelas sehingga setelah diteliti menjadi jelas dan dapat berupa hubungan kausal atau interaktif, hipotesis atau teori. Penyajian data bila telah didukung oleh data-data yang mantap, maka dapat dijadikan kesimpulan yang kredibel.

\section{Teknik Pemantapan Kredibilitas Penelitian}

Bungin (2008) menyatakan banyak hasil penelitian kualitatif diragukan kebenarannya karena beberapa hal, yaitu subjektivitas peneliti merupakan hal yang dominan dalam penelitian kualitatif, alat penelitian yang diandalkan adalah wawancara dan observasi mengandung banyak kelemahan ketika dilakukan secara terbuka terlebih karena tanpa kontrol (dalam observasi partisipasi), dan sumber data kualitatif yang kurang kredibel akan mempengaruhi hasil akurasi penelitian, untuk itu perlu melakukan "triangulasi", istilah yang digunakan oleh Denzin (dalam Bungin, 2008), yaitu menggunakan beberapa metode secara bersama-sama dalam suatu penelitian yang dilakukan secara linear atau secara silang, untuk menguji apakah data yang diperoleh dalam penelitian tersebut adalah sah dan benar.

Menurut Moleong (2004) triangulasi adalah pemeriksaan keabsahan data yang memanfaatkan sesuatu di luar data untuk keperluan pengecekan atau sebagai pembanding terhadap data tersebut. Denzin (dalam Bungin, 2008) menyatakan empat pelaksanaan teknis untuk menguji keabsahan suatu penelitian, antara lain:

\section{Triangulasi kejujuran peneliti}

Cara ini dilakukan untuk menguji kejujuran, subjektivitas, dan kemampuan merekam data di lapangan. Triangulasi ini dapat dilakukan dengan meminta bantuan peneliti lain untuk melakukan pengecekan langsung, wawancara ulang, serta merekam data yang sama di lapangan.

Triangulasi dengan sumber data

Teknik ini dilakukan dengan membandingkan dan mengecek derajat kepercayaan suatu informasi yang diperoleh melalui waktu dan cara yang berbeda dalam metode kualitatif yang dilakukan dengan (Patton dalam Bungin, 2008) membandingkan data hasil pengamatan dengan hasil wawancara, membandingkan apa yang dikatakan individu di depan umum dengan apa yang dikatakan secara pribadi, membandingkan apa yang dikatakan individu tentang situasi penelitian dengan apa yang dikatakan sepanjang waktu, membandingkan keadaan dan perspektif seseorang dengan 
berbagai pendapat dana pandangan orang lain seperti rakyat biasa, individu yang berpendidikan menengah atau tinggi, individu yang berada dan bekerja di pemerintahan, dan membandingkan hasil wawancara dengan isi suatu dokumen yang berkaitan.

Triangulasi dengan metode

Triangulasi ini dilakukan untuk melakukan pengecekan terhadap penggunaan metode pengumpulan data. Teknik ini juga dilakukan untuk menguji sumber data ketika melakukan wawancara dan observasi apakah akan menghasilkan informasi yang sama atau berbeda. Jika berbeda maka perlu untuk menjelaskan perbedaan tersebut dengan tujuan untuk mencari kesamaan data dengan metode yang berbeda.

Triangulasi dengan teori

Teknik ini dilakukan dengan menguraikan pola, hubungan, dan menyertakan penjelasan yang muncul dari analisis untuk mencari tema atau penjelasan pembanding. Secara induktif dilakukan dengan menyertakan usaha pencarian cara lain untuk mengorganisasikan data yang dilakukan dengan jalan memikirkan kemungkinan logis dengan melihat apakah kemungkin-kemungkinan yang muncul dapat ditunjang dengan data (Bardiansyah dalam Bungin, 2008).

\section{HASIL PENELITIAN}

\section{Karakteristik Responden}

Karakteristik responden penelitian dapat dilihat pada Tabel 1 (terlampir).

\section{Permasalahan yang Dialami oleh Responden}

Berdasarkan penelitian yang dilakukan, peneliti menemukan permasalahan yang dialami oleh responden yang dijabarkan pada Tabel 2 (terlampir).

\section{PEMBAHASAN DAN KESIMPULAN}

Berdasarkan hasil penelitian ini, responden merupakan seorang laki-laki yang berprofesi sebagai guru SLB mengalami permasalahan ketika awal bertugas sebagai guru SLB karena responden dimutasi dari sekolah reguler ke SLB. Pembahasan-pembahasan yang terdiri dari permasalahan pada awal bertugas di SLB, permasalahan mengajar di SLB, serta coping stress yang dilakukan atas permasalahan-permasalahan tersebut akan dipaparkan dalam pembahasan penelitian ini.

\section{Stressor}

Permasalahan yang dialami responden selama bertugas di SLB ada dua yakni permasalahan yang dihadapi responden pada awal penugasan di SLB dan permasalahan yang dihadapi responden ketika mengajar di SLB. Permasalahan responden pada umumnya berfokus pada proses adaptasi.

\section{Permasalahan pada Awal Penugasan di SLB}

Sebelum mendapat mutasi untuk mengajar di SLB, responden sempat mengajar di salah satu sekolah negeri di Singaraja. Pengalaman bekerja sebagai guru di sekolah reguler sempat responden rasakan kurang dari setahun tepatnya sekitar 8 bulan lamanya. Responden tidak menyangka ketika menerima surat perintah mutasi untuk mengajar di SLB. Responden yang merasa tidak memiliki kemampuan untuk dapat mengajar di sekolah luar biasa (SLB) karena responden belum pernah mendapatkan dasar pendidikan luar biasa (PLB) yang diperuntukkan untuk siswa berkebutuhan khusus dalam hal ini siswa tunagrahita. Keputusan yang diterima responden ini merupakan stressor yang menurut responden pada awalnya sempat membuatnya tertekan.

Menurut Taylor (2009), stress dapat diartikan sebagai menghadapi sesuatu yang tidak sesuai dengan apa yang dipikirkan kemudian ada tantangan yang dapat memunculkan stress. Responden yang tidak menduga akan ditugaskan di SLB sempat merasa kebingungan mengenai apa yang akan responden lakukan nanti ketika bekerja di SLB. Komunikasi dengan siswa berkebutuhan khusus serta bagaimana akan mengajarkan sebuah materi kepada siswa tersebut menjadi pemicu stress pada saat awal-awal responden menerima keputusan mutasi tersebut. Responden berpikir bahwa pekerjaan yang akan diterima sangat asing baginya.

Menurut Atwater (1983), stress pada individu dapat muncul ketika individu dihadapkan dengan lingkungan yang asing. Sesuai dengan teori tersebut, responden merasakan ketika awal masuk bekerja sebagai guru di SLB. Responden merasakan perbedaan yang sangat jauh antara anak-anak yang diajarnya dulu di sekolah reguler dengan anak-anak tunagrahita di SLB. Menurut responden anak-anak tunagrahita sering memunculkan perilaku yang susah di prediksi. Responden mengatakan bahwa susah untuk dapat mengontrol perilaku dari siswa tunagrahita karena berbeda secara kemampuan kognitif dengan siswa pada umumnya.

Permasalahan lain yang dialami oleh responden ketika awal bertugas di SLB adalah lingkungan disekitar sekolah yang kotor dan tidak kondusif. Responden yang terbiasa dengan lingkungan sekolah yang asri dan bersih ketika mengajar di sekolah reguler dulu merasa kaget dengan apa yang dijumpainya disekitar SLB tempat responden akan mengajar. Menurut Taylor (2009), lingkungan yang tidak kondusif seperti lingkungan yang kotor, suasana yang padat dan bising merupakan salah satu pemicu stress. Banyaknya pedagang yang berjualan disekitar area sekolah menyebabkan akses menuju sekolah menjadi lebih sempit, belum lagi bak penampungan sampah milik DKP Kabupaten Buleleng yang berada dekat dengan area sekolah menyebabkan responden merasa tidak nyaman dengan pemandangan di depan area sekolah.

Menurut Triyugo (1995), menciptakan dan menata lingkungan yang asri dapat mendatangkan pemikiran positif dari lingkungan menuju individu. Responden juga sempat mengemukakan bahwa menurut Ajaran Agama Hindu, ada konsep yang disebut dengan Tri Hita Karana yang mengatur tentang hubungan-hubungan antara manusia, Tuhan, serta alam semesta. Konsep Tri Hita Karana ini akan memberikan energi positif apabila hubungan antara manusia, Tuhan serta alam semesta berjalan seimbang. Kedua permasalahan tadi merupakan stressor yang sangat berpengaruh bagi responden sebagai pemicu stress utama ketika awal responden mendapatkan tugas untuk mengajar di SLB. 


\section{Permasalahan Ketika Mengajar di SLB}

Setelah mulai beradaptasi dengan lingkungan kerja yang baru di SLB, muncul lagi permasalahan-permasalahan baru ketika responden mengajar di kelas. Suasana proses belajar mengajar di kelas menurut responden lebih sulit dikontrol jika dibandingkan dengan suasana proses belajar di sekolah reguler. Fokus belajar siswa yang lemah menyebabkan responden harus lebih sabar dalam memberikan pelajaran. Responden mengatakan bahwa ketika mengajar di sekolah reguler siswa disana siswa disana cenderung lebih mudah untuk diatur. Pola pengajaran yang diterapkan lebih mudah diterima oleh siswa di sekolah reguler. Menurut Prameswari (2005) peran guru sangatlah penting dalam sistem pendidikan karena guru mempunyai tanggung jawab dalam proses belajar peserta didik. Responden yang pada awalnya tidak yakin dapat untuk mengajar serta mendidik anak tunagrahita merasa terbebani dengan tugasnya sebagai guru SLB. Keterbatasan komunikasi serta kemampuan siswa tunagrahita yang berbeda dari siswa pada umumnya menyebabkan responden bingung untuk memberikan pola pengajaran seperti apa yang akan diberikan di kelas.

Menurut Mangunsong (1998), siswa yang dikategorikan sebagai siswa tunagrahita ringan (untuk SLB C diperuntukkan bagi siswa tunagrahita ringan) adalah siswa yang memiliki kesulitan dalam menerima materi informasi, akan tetapi masih tetap bisa dididik, mampu menjaga diri, menjaga kebersihan, tidak terlalu bergantung, dapat bersosialisasi dengan teman dan keluarga, serta dapat menyesuasikan diri dengan lingkungan sekitar. Menurut responden, suasana kelas sulit dikontrol karena siswa hanya mampu fokus pada pelajaran di kelas dalam waktu yang singkat. Perhatian siswa pada pelajaran sangat gampang teralalihkan baik dari kejadiankejadian di luar kelas maupun dari sesama siswa yang tidak fokus sehingga melakukan hal-hal diluar kepentingan belajar. Terkadang siswa yang sudah tidak fokus mengganggu siswa yang masih fokus untuk belajar. Kejadian dari luar seperti orang yang sedang berjalan sangat mudah untuk mengambil perhatian dari siswa.

Menurut Taylor (2009), peristiwa yang tidak dapat dikontrol oleh individu merupakan salah satu pemicu stress. Mudahnya siswa kehilangan fokus, serta suasana kelas yang sulit dikontrol membuat responden harus lebih sabar ketika mengajar. Situasi ini tentu sangat menguras emosi serta rentan untuk memicu stress. Responden mengatakan rata-rata siswa yang ditanganinya bersifat sensitif terhadap nada suara apabila ditegur, sehingga apabila merasa jengkel oleh perilaku siswa responden merasa harus lebih menahan rasa emosinya dan memilih untuk berdialog dengan nada yang lebih halus agar siswa yang ditegur tidak merasa sedang dimarahi oleh guru.

Selain suasana kelas yang sulit dikontrol, pemicu stress yang lain ketika mengajar di kelas adalah siswa dengan 2. kecenderungan hiperkatif. Siswa dengan kecenderungan hiperaktif susah untuk diajak belajar di dalam kelas, bahkan untuk diajak duduk saja susah menurut penuturan responden. Responden mengatakan terkadang siswa dengan kecenderungan hiperkatif mondar-mandir keliling kelas dari awal responden mulai pelajaran hingga menjelang pelajaran berakhir. Siswa dengan kecenderungan hiperaktif ini terkadang jika sudah tidak ingin berada di kelas sering membuat ulah di kelas. Menurut Hendryk (2015), disfungsi sirkuit neuron diotak yang dipengaruhi oleh dopamine sebagai neurotranmiter pencetus gerakan yang sulit dikontrol pada anak hiperaktif.

Pendapat lain mengenai kecenderungan hiperaktif dikemukakan oleh Novita (2010), yang mengatakan bahwa anak dengan kecenderungan hiperaktif adalah anak yang mengalami gangguan pemusatan perhatian dengan hiperaktivitas (GPPH) atau attention deficit and hyperactivity disorder (ADHD) atau dengan istilah lain kondisi ini juga disebut sebagai gangguan hiperkinetik. Responden mengatakan memang sangat susah untuk dapat mengendalikan siswa dengan kecenderungan hiperaktif di dalam kelas. Setiap tahun responden selalu mendapatkan siswa dengan kecenderungan hiperaktif dikelasnya. Hal ini merupakan stressor yang selalu responden hadapi setiap kali responden mengajar di kelas.

Berbeda dengan kedua stressor diatas, stressor lain juga datang dari luar sekolah yakni dari orangtua siswa. Menurut responden orangtua siswa terlalu membebankan pendidikan anak mereka kepada guru. Orangtua siswa menginginkan anaknya dapat dengan cepat untuk bisa membaca dan menulis, sedangkan orangtua tidak mengerti bahwa siswa seperti itu harus diberikan pengajaran secara perlahan dan penuh perhatian.

Menurut Shinta (2011), kesulitan belajar merupakan bidang yang sangat luas, dan sangat kompleks untuk dipelajari, karena menyangkut sekurang-kurangnya aspek psikologis, neurologis, pendidikan dan aspek kehidupan sosial anak dalam keluarga atau masyarakat. Responden merasa sangat terbebani ketika orangtua siswa selalu ingin perkembangan anaknya secara cepat.

Menurut Taylor (2009), beban kerja yang terlalu berat dapat menyebabkan stress serta menurunnya produktivitas dari individu. Dari kategori siswa tunagrahita milik Mangunsong (1998), siswa yang dikategorikan sebagai siswa tunagrahita ringan (untuk SLB C diperuntukkan bagi siswa tunagrahita ringan) adalah siswa yang memiliki kesulitan dalam menerima materi informasi, akan tetapi masih tetap bisa dididik. Pendidikan seperti berhitung, membaca serta menulis masih sangat mampu untuk diterima oleh siswa tunagrahita ringan. Dalam prosesnya membutuhkan waktu yang lebih lama dari siswa pada umumnya dikarenakan kemampuan untuk menerima instruksi masih dibawah siswa pada umumnya.

1. Coping stress Atas Permasalahan yang Dihadapi Responden Selama Bertugas di SLB

Setiap permasalahan yang dialami oleh responden seperti yang telah dipaparkan sebelumnya diatasi responden dengan melakukan coping stress. Coping stress adalah pikiran yang mengarahkan perilaku individu untuk mengorganisir atau memanajemen perilaku dari situasi yang penuh tekanan atau stressor (Taylor, 2009). Menurut Pargament (1997) coping stress adalah suatu proses yang melibatkan individu di 


\section{G.A WIRAGITA \& D.H TOBING}

dalamnya untuk mencapai makna dari keadaan yang dapat menimbulkan stress. Individu secara aktif melakukan pendekatan, menghindari, mengantisipasi dan menilai keadaan dalam hidup berdasarkan keterlibatan individu untuk mencari makna. Definisi lainnya disampaikan oleh Sarafino dan Smith (2010) bahwa coping stress merupakan cara yang dilakukan oleh individu untuk mengadaptasi situasi yang dapat menimbulkan stress.

Responden yang menghadapi stressor pada awal penugasan di SLB serta pada saat mengajar di kelas melakukan coping stress untuk meminimalisir stressor yang muncul. Untuk mengurangi stress pada awal penugasan di SLB, responden melakukan pelatihan dasar pendidikan pelatihan luar biasa (PLB) serta meminta saran dari guru-guru lain yang terlebih dahulu mengajar di SLB agar dapat mengajar secara maksimal di SLB. Hal ini dilakukan agar responden dapat berkomunikasi dan memberi pelajaran pada siswa tunagrahita yang pada awalnya responden tidak memiliki gambaran mengenai siswa tunagrahita, cara berkomunikasi pada siswa tunagrahita serta cara mengajar yang efektif untuk siswa tunagrahita. Ketika lingkungan di sekitar yang dihadapi tidak sesuai dengan apa yang responden harapkan, responden berusaha untuk memperbaikinya dengan cara meminta bantuan dari salah satu saudara responden yang tinggal dekat dengan lingkungan sekolah untuk membantu membersihkan lingkungan sekitar sekolah pada sore hari ketika mereka sedang tidak ada kegiatan.

Coping stress yang dilakukan oleh responden ketika mengajar di kelas waktu situasi proses belajar mengajar di kelas sulit untuk dikontrol adalah dengan menyelipkan waktu untuk bercanda pada saat mengajar agar siswa tidak merasa jenuh karena siswa memang memiliki fokus yang lemah untuk tetap berkonsentrasi dalam belajar di kelas. Ketika menghadapi siswa dengan kecenderungan hiperaktif yang sulit untuk diam dan menerima pelajaran di kelas responden melakukan coping stress dengan cara mendatangi anak dan menanyakan sedang melakukan kegiatan apa serta permasalahan yang dimiliki dikelas yang menyebabkan siswa tersebut tidak duduk dikursinya dengan harapan ketika responden datang untuk memperhatikannya, siswa tersebut mau untuk duduk dan tidak mengganggu situasi proses belajar mengajar di kelas agar siswa lainnya dapat kembali fokus menerima pelajaran sebelum konsentrasinya teralihkan oleh perilaku siswa dengan kecenderungan hiperaktif tadi. Stressor lain yang datang dari luar sekolah yakni dari orangtua siswa yang menginginkan anaknya dapat dengan cepat untuk bisa membaca dan menulis. Coping stress yang dilakukan untuk menghadapi stressor tersebut adalah dengan memberi penjelasan kepada orangtua siswa tentang kondisi siswa ketika responden bertemu orangtua siswa pada waktu pulang sekolah. Responden selalu menyempatkan diri ketika pulang sekolah untuk sekedar bertemu dengan orangtua siswa untuk menjelaskan kondisi anaknya agar lebih diperhatikan guna meningkatkan kemampuan belajar dari siswa.
Berdasarkan hasil dari penelitian, coping stress yang dilakukan responden cenderung menggunakan problemfocused coping (PFC). Menurut Lazarus dan Folkman (1984) menuliskan bahwa fungsi coping stress mengarah pada tujuan pelaksanaan suatu strategi. Terdapat dua fungsi utama coping, yaitu emotion-focused coping (EFC) dan problemfocused coping (PFC). Usaha melakukan PFC seringkali mengacu pada bagaimana individu memaknai permasalahan, menghasilkan solusi-solusi alternatif, menimbang kerugian dan keuntungan dari alternatif-alternatif yang ada, memilih alternatif, dan bertindak (Lazarus dan Folkman, 1984).

Sesuai dengan hasil penelitian, diketahui bahwa permasalahan yang dihadapi responden ada dua yaitu permasalahan ketika awal penugasan di SLB dan permasalahan ketika mengajar di SLB. Permasalahan yang dihadapi responden ketika awal penugasan di SLB adalah responden merupakan guru sekolah reguler yang tidak memiliki dasar pendidikan luar biasa (PLB). Permasalahan lain yang dihadapi responden pada awal penugasan di SLB adalah lingkungan sekitar sekolah yang kotor, berbeda dengan lingkungan sekolah tempat responden mengajar sebelumnya yang asri dan bersih.

Permasalahan yang kedua adalah permasalahan ketika responden mengajar di SLB. Permasalahan yang dihadapi oleh responden ketika mengajar di SLB adalah suasana kelas yang lebih sulit dikontrol oleh responden jika dibandingkan dengan suasan kelas pada sekolah reguler. Permasalahan lain yang dihadapi oleh responden ketika mengajar di SLB adalah siswa hiperaktif. Siswa hiperaktif yang sulit untuk diam dan menerima pelajaran di kelas merupakan permasalahan yang paling sering responden jumpai karena hampir setiap tahun selalu ada siswa yang hiperkatif. Permasalahan yang dihadapi oleh responden ketika mengajar di SLB yang selanjutnya berasal dari luar sekolah yakni dari orangtua siswa. Orangtua siswa yang menginginkan anaknya untuk dapat dengan cepat mampu membaca serta menulis membuat responden merasa tertekan.

Coping stress yang dilakukan oleh responden untuk mengurangi stress ketika bertugas di SLB adalah dengan mengikuti pelatihan pendidikan luar biasa (PLB), membersihkan lingkungan sekolah bersama saudara ketika sedang tidak ada kegiatan di rumah, dan memberikan jeda pada saat siswa sudah tidak fokus untuk belajar. Responden juga bercerita tentang permasalahan di sekolah kepada istri yang kebetulan satu profesi dengan responden yakni sebagai guru dan keluarga, sharing bersama sesama rekan guru, dan bercerita kepada orangtua siswa. 


\section{DAFTAR PUSTAKA}

Atwater, E. (1983). Psychology of adjustment. New Jersey: PrenticeHall.

Babbie, E. R. (2013). The practice of social research (13 ${ }^{\text {th }}$ Ed.). USA: Cengage Learning.

Bungin, B. (2008). Penelitian kualitatif: komunikasi, ekonomi, kebijakan publik, dan ilmu sosial lainnya. Jakarta: Kencana.

Daymon, C., \& Holloway, I. (2011). Qualitative research methods in public relations and marketing communications. New York: Routledge.

Fitria, D. S. (2009). Implementasi pendidikan sekolah luar biasa di indonesia. Jakarta: Dokum Publisher.

Folkman, S., Lazarus, R. S., Dunkel-Schetter, C., DeLongis, A., \& Gruen, R. J. (1986). Dinamics of a stressful encounter: Cognitive appraisal, coping, and encounter outcomes. Journal of Personality and Social Psychology), 50(5), 992-1003. doi:10.1037/00223514.50.5.992.

Hari. S. (2005). Dasar pendidikan luar biasa. Jakarta: Wirda Jaya.

Hendryk. S. (2015). Menerapkan pola asuh pada anak berkebutuhan khusus. Surabaya: Teratai.

Herdiansyah. H. (2015). Metodologi penelitian kualitatif untuk ilmu psikologi. Jakarta: Salemba Humanika.

Johnson, R. B., \& Christensen, L. (2014). Educational research: Quantitative, qualitative, and mixed Approaches. USA: Sage Publications

Lazarus, R. S., \& Folkman, S. (1984). Stress, appraisal, and coping. New York: Springer Publishing Company.

Lazarus, R. S. (1999). Stress and emotion: a new synthesis. New York: Springer Publishing Company.

Miles, M. B., \& Huberman, A. M. (2014). Analisis data kualitatif: Buku sumber tentang metode -metode baru (terjemahan: Rohidi). Jakarta: Ul-Press.

Moleong, L. J. (2014). Metodologi penelitian kualitatif (Edisi Revisi). Bandung: Remaja Rosdakarya.

Mulyana, D. (2008). Metodologi penelitian kualitatif paradigma baru ilmu komunikasi dan ilmu sosial lainnya. Bandung: Remaja Rosdakarya.

Na'im. (2011). Petunjuk teknis pelaksanaan peraturan bersama tentang penataan dan pemerataan guru PNS. http://dikdas .kemdikbud.go.id /application/media /file/ Juknis\% 20Peraturan\%205\% 20Menteri \% 20 tetang $\% \quad 20$ tentang $\%$ 20Penataan\%20dan\%20Pemerataan\% $20 \mathrm{Guru} \%$ 20Pegawai\%20Negeri\%20Sipil.PDF. Diakses pada tanggal 2 Oktober 2016.

Novita, Y. (2010). Kenali anak kita sejak dini. Jakarta: Marga Utama

Pargament, K. I. (1997). The psychology of religion and coping: Theory, research, practice. New York: Guilford Press.

Pawito. (2007). Penelitian komunikasi kualitatif. Yogyakarta: LKiS.

Prameswari, D. (2005). Stres kerja pada guru SLB bagian C ditinjau dari kecerdasan emosional. http://eprints.unika.ac.id/4889/1/97.40.2504. Diakses pada tanggal 5 Oktober 2016.

Pristi, D. (2013). Jenis-jenis SLB. http://12035dp.blogspot.com /2013/05/jenis-jenis-slb.html. Diakses pada 5 Oktober 2016.

Rahmawati, S. H. (2013). Stres pada guru / dosen. http:// shrahmawati .dosen.unimus.ac.id/2013/02/24/strespada-guru-dosen/. Diakses pada 5 Oktober 2016.

Rakhmat, J. (2003). Psikologi agama: Sebuah pengantar. Bandung:
Mizan.

Sarafino, E. P., \& Smith, T. W. (2010). Health psychology: Biopsychosocial interactions $\left(7^{\text {th }} \mathrm{Ed}\right)$. New York: John Wiley.

Shinta, U. (2011). Panduan pengajaran pada anak-anak bagi orang tua. Semarang: Tunas Muda.

Straus, A., \& Corbin, J. (2013). Dasar-dasar penelitian kualitatif tata langkah dan teknik-teknik reoritisasi data. Yogyakarta: Pustaka Pelajar.

Sugiyono. (2014). Metode penelitian kombinasi (Mixed methods). Bandung: Alfabeta.

Sulistyowati, A. (2011). Siswa tunagrahita itu menanti yang tak pasti.

http:// megapolitan.kompas.com/read/2011/08/11/03433995/ Siswa.Tunagrahita.Itu.Menanti.yang.Tak.Pasti. Diakses pada 3 Oktober 2016.

Taylor, S. E. (2009). Health psychology. Los Angeles: McGraw-Hill.

Triyugo, D. (1995). Symphoni harmoni, sebuah perspektif dari alam. Surabaya: Merah Putih.

Woodside, A. G. (2010). Case study research: Theory, methods, practice. USA: Emerald Group Publishing.

Yin, R. K. (2014). Studi kasus: desain \& metode. Jakarta: Rajawali Press.

Yin, R. K. (2016). Qualitative research from start to finish $\left(2^{\text {nd }}\right.$ Ed). New York: The Guillford Press. 


\section{LAMPIRAN}

Tabel 1

Karakteristik responden

\begin{tabular}{ll}
\hline Inisial & DA \\
\hline Usia & 29 tahun \\
Jenis Kelamin & Laki-laki \\
Alamat & Br. Tegal, Singaraja \\
Suku & Bali \\
Agama & Hindu \\
Pendidikan Terakhir & Sarjana Pendidikan (S1) \\
Jurusan & Agama Hindu \\
Lama Mengajar & Hampir 3 Tahun \\
\hline
\end{tabular}




\section{LAMPIRAN}

Tabel 2

Permasalahan yang dialami oleh responden

\begin{tabular}{|c|c|c|}
\hline & No. & Hasil Penelitian \\
\hline \multirow{6}{*}{ 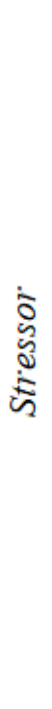 } & 1 & $\begin{array}{l}\text { Permasalahan yang dihadapi responden pada awal } \\
\text { penugasan di SLB }\end{array}$ \\
\hline & \multirow{5}{*}{2} & $\begin{array}{l}\text { a. Bukan guru khusus untuk siswa tunagrahita, karena } \\
\text { responden sebelumnya mengajar di sekolah } \\
\text { reguler. Tidak memiliki kemampuan dasar } \\
\text { pendidikan luar biasa (PLB) } \\
\text { b. Lingkungan sekitar sekolah yang kotor }\end{array}$ \\
\hline & & $\begin{array}{l}\text { Permasalahan yang dihadapi responden ketika } \\
\text { mengajar di SLB }\end{array}$ \\
\hline & & $\begin{array}{l}\text { a. Suasana proses belajar mengajar di kelas yang } \\
\text { lebih sulit dikontrol jika dibandingkan dengan } \\
\text { waktu mengajar di sekolah reguler }\end{array}$ \\
\hline & & $\begin{array}{l}\text { b. Siswa dengan kecenderungan hiperaktif yang sulit } \\
\text { untuk diam dan menerima pelajaran di kelas }\end{array}$ \\
\hline & & $\begin{array}{l}\text { c. Orangtua siswa yang ingin anaknya mampu dengan } \\
\text { cepat untuk bisa membaca dan menulis }\end{array}$ \\
\hline
\end{tabular}

\begin{tabular}{|c|c|c|}
\hline & No. & Hasil Penelitian \\
\hline 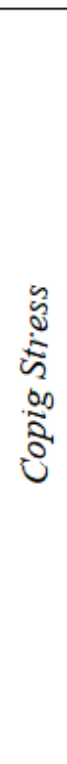 & 3 & $\begin{array}{l}\text { Coping stress atas permasalahan yang dihadapi } \\
\text { responden pada awal penugasan di SLB dan } \\
\text { permasalahan yang dihadapi responden ketika } \\
\text { mengajar di SLB } \\
\text { a. Mengikuti pelatihan serta seminar-seminar tentang } \\
\text { pendidikan luar biasa (PLB) } \\
\text { b. Mengajak saudara responden yang kebetulan } \\
\text { tinggal di dekat sekolah untuk membantu } \\
\text { membersihkan lingkungan sekitar sekolah } \\
\text { c. Sering menyelipkan waktu untuk bercanda pada } \\
\text { saat mengajar ketika siswa mulai tidak fokus untuk } \\
\text { menerima pelajaran } \\
\text { d. Lebih memperhatikan tingkah laku siswa ketika } \\
\text { mengajar dengan cara mendatangi meja siswa } \\
\text { e. Memberikan pengertian mengenai kondisi siswa } \\
\text { kepada orangtua ketika bertemu pada saat jam } \\
\text { pulang sekolah }\end{array}$ \\
\hline
\end{tabular}

